\title{
CRITICAL SUCCESS CRITERIA FOR PUBLIC-PRIVATE PARTNERSHIP PROJECTS: INTERNATIONAL EXPERTS' OPINION
}

\author{
Robert OSEI-KYEI a,*, Albert P. C. CHAN a, Arshad Ali JAVED a, Ernest Effah AMEYAW a \\ ${ }^{a}$ Department of Building and Real Estate, The Hong Kong Polytechnic University, Hung Hom, Hong \\ Kong, China
}

Received 26 August 2015; accepted 25 March 2016

\begin{abstract}
Public-Private Partnership (PPP) projects success is the ultimate goal of practitioners and government organizations. In this regard, the last decade has seen considerable research into the critical success factors (CSFs) for PPP projects. However, a very important subject which has received very little attention in the normative literature is the success criteria for PPP projects. This paper examines the general perception of purposively sampled international PPP experts on a set of 15 PPP projects success criteria derived from literature. The survey results show that all the success criteria are critical; however seven are very critical. These include: effective risk management; meeting output specifications; reliable and quality service operations; adherence to time; satisfying the need for public facility/service; long-term relationship and partnership; and profitability. The findings of this study are impactful because they inform practitioners on the key measures to consider when evaluating the success of PPP projects. More research should be conducted to further develop a composite success index that could be used to objectively assess the success levels of different PPP projects. In addition, the perceptions of different stakeholders on PPP projects success criteria and the causal relationship between CSFs and success criteria for PPP projects should be investigated.
\end{abstract}

KEYWORDS: Public-Private Partnership; Critical success factors; Success criteria; Project success; Project management

\section{INTRODUCTION}

In recent times, the public-private partnership (PPP) concept has gained considerable attention among governments in both developed and developing countries (Cheung et al. 2012). With PPP schemes, governments are now able to tap into the private sector's expertise and skills in developing sustainable and modernized public infrastructure (Menard, Peeroo 2011; Chan et al. 2009). Private investors also tend to benefit hugely in PPP arrangements through government's financial support and guarantees (Osei-Kyei et al. 2014). Unfortunately, despite the enthusiasm from the public and private sectors, there has been a slow progress in the implementation of the PPP policy as well as an increased number of failed or distressed projects particularly in countries in the developing regions (World Bank 2015; Osei-Kyei, Chan 2016; Zhang 2005; Chan et al. 2010; Liu, Wilkin-

* Corresponding author. E-mail: oseikyeirobert@yahoo.com son 2011). Hence, the last decade has seen significant amount of research into the critical factors that contribute to the successful implementation of PPPs both in developing and developed countries (Ke et al. 2009; Osei-Kyei, Chan 2015). Elements including strong private consortium (Nisar 2013; Dulaimi et al. 2010), appropriate risk allocation and sharing (Jefferies et al. 2002; Babatunde et al. 2012), political support (Gannon, Smith 2011; Li et al. 2005a), public/community support (Kumaraswamy, Morris 2002) and transparent procurement (Jamali 2004) are the mostly identified critical success factors (CSFs) for PPP projects.

Although the normative literature on the CSFs for PPPs provides in-depth insights into the effective ways of delivering projects, yet a relevant question still remains unanswered; that is: "what are the critical criteria for determining PPP projects success?" Essentially, addressing this question is vital because without a thorough and indepth knowledge on the critical success criteria 
for PPP projects, it would be very challenging for practitioners to appropriately establish whether an implemented project has been successful or not (Chan et al. 2002; Al-Tmeemy et al. 2011). Though there exist an extensive body of literature on project success criteria, these grey and contemporary literature mainly focus on the traditionally procured construction projects (see Lim, Mohamed 1999; Baccarini 1999; Bryde, Robinson 2005; Frodell et al. 2008; Al-Tmeemy et al. 2011; Ahadzie et al. 2008; Elattar 2009). However, considering the uniqueness of PPP projects, it is likely their success criteria will differ from the traditionally procured projects (Akintoye et al. 2003; Skietrys et al. 2008). Therefore, a thorough discussion and empirical work on the critical success criteria for PPP projects is required in order to complement and further expand both practitioners and researchers understanding of the ways of delivering successful PPP projects.

Against this backdrop, this paper explores the critical success criteria for PPP projects based on an empirical questionnaire survey geared towards targeted international PPP experts. Adopting an international survey for this study was deemed appropriate because it offers a cross-cultural perspective that is useful to practitioners in both developed and developing countries. It is hoped that the results of this study would enhance the practice and implementation of PPPs in both developed and developing countries. Further, considering that this study seeks to only highlight the critical success criteria for PPP projects, the results are useful for the formulation of relevant hypothesis for a much deeper investigation in the future.

\section{LITERATURE REVIEW}

\subsection{Success criteria for construction projects}

Project success has been defined in diverse ways by researchers and each definition varies depending on the type and size of project (Parfitt, Savido 1993; Chan, A. P. C., Chan, A. P. 2004). Generally, project success is described as the achievement of some externally perceived criteria (Ashley et al. 1987; Rosenau 1984). Whereas criteria denote a principle or standard by which something is judge (Lim, Mohamed 1999). Essentially, the criteria for assessing construction projects success have been debated for the past decades and there exist no acceptable checklist (Brown, Adams 2000; Ahadzie et al. 2008). Nevertheless, project success is tra- ditionally assessed based on three major criteria namely: time; cost and quality (Hatush, Skitmore 1997; Cheung et al. 2000; Khosravi, Afshari 2011). These success criteria are what Atkinson (1999) referred to as the "iron triangle".

Over time, researchers have criticized the exclusive use of the conventional success measures of time, cost and quality for construction projects. Some have suggested the incorporation of other subjective success measures. For instance, Ahadzie et al. (2008) identified environmental impact and customer satisfaction as important additional success measurements aside the traditional set of success criteria for mass housing building projects (MHBP) in developing countries. Furthermore, Toor and Ogunlana (2010) emphasized that safety, effectiveness, satisfaction of stakeholders, efficient use of resources and reduced conflicts are the success criteria which are very important in assessing large scale construction projects success compared to the traditional measures. Also Westerveld (2003) strongly opined that clients' appreciation, contracting partners' appreciation, stakeholders' appreciation, users' appreciation and project personnel appreciation are important success measures aside the conventional criteria of time, cost and quality. Notwithstanding, the traditional success criteria do not fully incorporate the proper implementation of construction projects but mainly focus on the contribution of profit (Cserháti, Szabó 2014). In addition, the traditional measures are geared towards the satisfaction of project clients and contractors without considering other external stakeholders' expectations (Westerveld 2003; Al-Tmeemy et al. 2011). In this regard, it is always essential for project managers to establish a clear set of success criteria which integrate both objective and subjective measures in order to properly evaluate construction projects success (Cox et al. 2003).

\subsection{Criteria for measuring the success of PPP projects}

Although there is a large strand of literature on success criteria, importantly majority of past studies have focused on the traditionally procured projects. Considering the complexity and value of PPP projects, clearly just a hand full of success criteria of traditionally procured projects may be applicable to PPP projects. Nonetheless, this section attempts to review studies that have closely discussed on PPP projects success criteria. 
Dixon et al. (2005) through semi-structured interviews with 11 PFI stakeholders found out that different groups of stakeholders have different ways of measuring PFI projects success. However, they emphasized that feedback from users, efficient and cost-effective procurement process, time, budget and meeting specifications are some of the key success criteria for PFI projects. Also, Zhang (2006a) examined the public client's best value-objectives in PPPs based on a questionnaire survey of international PPP experts. He grouped the public client's best value-objectives into five major components; these include: "exploring private finance initiatives for enhanced infrastructure development"; "maximizing the benefits to the public sector"; "improving construction engineering and management process"; "utilizing private sector technologies and management skills for innovation and improved efficiencies"; and "improving the scope for private sector participation to promote the development of priority and other needed projects".

Yuan et al. (2009) identified and evaluated 15 performance objectives of PPP projects based on a comprehensive literature review and questionnaire survey of experts. They found out that acceptable quality of project, quality public service and project executed within budget are the top three performance objectives of PPP projects. Further, they identified 48 performance indicators of PPP projects and grouped them into five major components. These include: physical characteristics of projects indicators; innovation and learning indicators; stakeholders indicators; project process indicators; and financial and marketing indicators.

Also, Mladenovic et al. (2013) through brainstorming with experts along with a thorough review of literature presented a two-layer approach for measuring the performance of PPP projects. They indicated that the first layer should focus on the fulfilment of the ultimate objectives of the stakeholders, whilst the second layer examines the fulfilment of the individual performance objectives of each stakeholder (i.e. public, private and users). The ultimate objectives identified include customer and owner satisfaction for the private sector, profitability, efficiency, value for money, environmental impact of project, level of services and effectiveness.

Furthermore, Liu et al. (2015a) through an extensive review of literature developed a life-cycle conceptual model for measuring the performance of PPP projects. The model consists of five principal components of performance measures. These include: stakeholder satisfaction; strategies; pro- cesses; capabilities; and stakeholder contribution. Liyanage and Villalba-Romero (2015) also analysed toll road projects and developed a matrix of 11 key performance indicators and 32 performance measures which were categorized from the perspectives of project management, stakeholder and contract management.

The brief overview of germane literature greatly attests to the fact that success criteria in PPP projects have received very little attention. In essence, previous related studies mainly focused on developing data measures that could be used to evaluate the actual and expected performance of PPP projects in terms of their efficiency, quality and effectiveness. Further, past studies had not sought to evaluate the critical criteria that define PPP project success or better still explore the general perception of practitioners on the key indicators of a successful PPP project. This paper therefore seeks to bridge this knowledge gap.

\subsection{The relationship between CSFs and success criteria for PPP projects}

Although CSFs and success criteria have been used interchangeably by some management literature, these concepts are different but related. As explained by Lim and Mohamed (1999), CSFs are the set of circumstances and facts, which facilitate project success. This implies that CSFs are actually the driving forces to achieve successful project outcomes (Rockart 1982). They are not themselves the successful outcomes. On the other hand, success criteria are the successful outcomes of projects and they are the parameters on which success is measured (Chan et al. 2002).

In PPP project implementation, both concepts (i.e. CSFs and success criteria) are important in achieving success; they collectively operative within the framework of PPP projects success. In essence, there is a tight relationship between them in achieving PPP projects success (Lim, Mohamed 1999). Technically, to determine PPP projects success, the success criteria for PPP projects act as the dependent variables, whereas the CSFs for PPP projects become the independent variables. To clearly illustrate the difference and relationship, consider reduced public and political protest as a critical success criterion for PPP projects. For this criterion to be realised, it depends of several critical factors, including transparency, frequent communication and user fee adjustments. Though the critical factors influence the projects' success, they do not form the basis for judgement. 


\section{RESEARCH METHODOLOGY}

\subsection{Prior literature and pre-testing}

The first critical step in this study was to identify an exhaustive set of success criteria for PPP projects from previous studies that focused on the success criteria for general construction projects and PPP related projects. This effort formed part of a broader research project which aims to develop a best practice framework for PPP implementation in Ghana drawing on international experiences (Osei-Kyei, Chan 2017). From the comprehensive review, a set of 15 PPP projects success criteria was derived. The set of 15 success criteria was then sent to three international PPP experts from both the academic and industrial sectors for pre-testing. The purpose of the pre-testing was to ascertain the adequacy and clarity of the criteria.
The experts confirmed the sufficiency and clarity of the criteria with minor modifications in the descriptions of some criteria. Table 1 presents the set of 15 success criteria for PPP projects.

\subsection{International expert survey}

An empirical questionnaire survey was conducted on targeted PPP experts (i.e. academic and industry practitioners) worldwide. The questionnaire required experts to rate on a seven point Likert scale the importance of each success criterion for PPP projects. Targeted experts were selected based on two predefined criteria viz; the respondent should have adequate hands-on experience and/or have conducted research in PPP project delivery. Secondly the respondent should have in-depth knowledge on PPP projects success (Osei-Kyei, Chan 2017). Given these criteria it was expected that the

Table 1. Set of success criteria for PPP projects from pertinent literature

\begin{tabular}{|c|c|c|}
\hline PPP projects success criteria & Definitions & Sources \\
\hline $\begin{array}{l}\text { Reduced litigations and } \\
\text { disputes }\end{array}$ & $\begin{array}{l}\text { Contract litigations and disputes are minimized } \\
\text { throughout the project lifecycle }\end{array}$ & $\begin{array}{l}\text { Zhang (2006b), Chan, A. P. C. } \\
\text { and Chan, A. P. (2004) }\end{array}$ \\
\hline $\begin{array}{l}\text { Reduced public and } \\
\text { political protests }\end{array}$ & $\begin{array}{l}\text { The reduction of agitations and protests which often } \\
\text { arise due to increases in tariffs, lack of transparency, } \\
\text { corruption etc. }\end{array}$ & Zhang (2006a) \\
\hline Effective risk management & $\begin{array}{l}\text { Risks are properly identified. The risk sharing and } \\
\text { transfer mechanism are agreed and effectively } \\
\text { implemented by the public and private parties }\end{array}$ & $\begin{array}{l}\text { Li et al. (2005b), Liu et al. } \\
\text { (2015) }\end{array}$ \\
\hline $\begin{array}{l}\text { Effective technology } \\
\text { transfer and innovation }\end{array}$ & $\begin{array}{l}\text { Technical knowledge and innovation are effectively } \\
\text { shared among stakeholders particularly with local } \\
\text { practitioners }\end{array}$ & Mladenovic et al. (2013) \\
\hline $\begin{array}{l}\text { Environmental } \\
\text { performance }\end{array}$ & $\begin{array}{l}\text { Project does not affect the health and safety of } \\
\text { occupants or the environment }\end{array}$ & $\begin{array}{l}\text { Zhang (2006a, 2006b), Chan } \\
\text { et al. }(2002)\end{array}$ \\
\hline $\begin{array}{l}\text { Long term relationship and } \\
\text { partnership }\end{array}$ & $\begin{array}{l}\text { Cordial relationship and well established } \\
\text { coordination are instituted among stakeholders }\end{array}$ & $\begin{array}{l}\text { Yuan et al. (2012), Jacobson } \\
\text { and Choi (2008) }\end{array}$ \\
\hline $\begin{array}{l}\text { Meeting output } \\
\text { specifications }\end{array}$ & $\begin{array}{l}\text { Project meets the expected output standards/ } \\
\text { requirements and delivery }\end{array}$ & $\begin{array}{l}\text { Liyanage and Villalba-Romero } \\
\text { (2015), Lam and Javed (2015) }\end{array}$ \\
\hline Adherence to budget & $\begin{array}{l}\text { Project is constructed according to the estimated cost } \\
\text { and it is without any operational cost overruns }\end{array}$ & $\begin{array}{l}\text { Liyanage and Villalba-Romero } \\
\text { (2015), Cheung et al. }(2000), \\
\text { Al-Tmeemy et al. (2011) }\end{array}$ \\
\hline Adherence to time & $\begin{array}{l}\text { Project is constructed on/before time schedule for } \\
\text { commissioning }\end{array}$ & $\begin{array}{l}\text { Khosravi and Afshari (2011), } \\
\text { Al-Tmeemy et al. (2011) }\end{array}$ \\
\hline $\begin{array}{l}\text { Satisfying the need for } \\
\text { public facility/service }\end{array}$ & $\begin{array}{l}\text { An implemented PPP project satisfies fully the need } \\
\text { for a public facility/service }\end{array}$ & Yuan et al. (2009) \\
\hline Profitability & $\begin{array}{l}\text { A continuous income/profit is received by parties } \\
\text { during project operation }\end{array}$ & Mladenovic et al. (2013) \\
\hline $\begin{array}{l}\text { Local economic } \\
\text { development }\end{array}$ & $\begin{array}{l}\text { Project contributes to the economic development of } \\
\text { the community within which the project is developed }\end{array}$ & Zhang (2006b) \\
\hline $\begin{array}{l}\text { Reduced project life cycle } \\
\text { cost }\end{array}$ & $\begin{array}{l}\text { Lower life cycle cost is realised, which enhances the } \\
\text { project's value for money }\end{array}$ & Yuan et al. (2009) \\
\hline $\begin{array}{l}\text { Reduced public } \\
\text { administrative cost }\end{array}$ & $\begin{array}{l}\text { Lower cost is incurred by the public sector in the } \\
\text { administration of the project because major project } \\
\text { risks are allocated to the private sector }\end{array}$ & $\begin{array}{l}\text { Li et al. (2005b), Yuan et al. } \\
\text { (2009), Zhang (2006a) }\end{array}$ \\
\hline $\begin{array}{l}\text { Reliable and quality } \\
\text { service operations }\end{array}$ & $\begin{array}{l}\text { Continuous and uninterrupted project services are } \\
\text { provided and according to the satisfaction of users }\end{array}$ & $\begin{array}{l}\text { Ng et al. (2012), Meng et al. } \\
\text { (2011), Dixon et al. (2005) }\end{array}$ \\
\hline
\end{tabular}


appropriate experts would be engaged to provide rich information on the success criteria for PPP projects. Essentially, expert sampling (i.e. purposive sampling approach) has been widely used in PPP research studies (e.g. see Zhang 2005; Zou et al. 2014; Osei-Kyei et al. 2014; Ameyaw, Chan 2015). This is because many countries' PPP markets are still developing particularly those in the developing regions (World Bank 2015). Therefore, purposive sampling is always the most suitable technique to adopt in PPP research studies (Babatunde et al. 2012). Most importantly, the complexity of the qualitative decision factors often requires experts with adequate experience in practice and/ or research in PPP project management.

In total, 310 experts from both academia and industry were sourced and identified from dedicated public and private organizations (including Partnerships U.K, Partnerships Victoria, Canadian Council for PPP (CCPPP)), international financial institutions (including Asia Development Bank, Public-Private Infrastructure Advisory Facility) and publications on PPPs in peer reviewed academic journals, conferences and books (OseiKyei, Chan 2017). The small target frame (310) is attributed to the pre-defined criteria employed, which required highly experienced and knowledgeable experts to deal with the complex qualitative decision factors. Notwithstanding, the number of experts identified (310) is large compared to the target frame of a similar study conducted by Zhang (2005) (200). Questionnaires were then sent by emails to targeted experts with options of answering the questionnaire on the "Survey Monkey" online questionnaire platform or completing and returning the attached questionnaire. This flexibility was intended to increase the response rate of the survey.

A four-week period was given to the experts and after sending a series of reminders within the period, 45 responses were received. However, three responses were found to be incomplete and were discarded, leaving 42 valid responses for further analysis (Osei-Kyei, Chan 2017). Although a low response rate of approximately $14 \%$ is recorded, the sample size of 42 is considered reasonable when compared with similar studies (Zhang 2005, 2006b (46 responses); Osei-Kyei, Chan 2017). Nonetheless, small samples are not uncommon in an international e-mail/web-survey based research in PPP studies (e.g. see Ameyaw, Chan 2015 (35 responses out of 326); Salman et al. 2007 (15 out of 188 for first survey and 12 out of 128 for second survey); Sachs et al. 2007 (29 responses); Osei-Kyei, Chan
2017). In addition, the number of industrial and/or research years of experience in PPPs (Table 2) and diverse cultural backgrounds (Table 3) of experts contribute to the reliability and genuineness of the survey responses. A detailed background of experts is shown in Tables 2 and 3 (Osei-Kyei, Chan 2017).

As shown in Tables 2 and 3, a balanced view is realized in this study with $43 \%$ and $57 \%$ of experts coming from the academic and industrial sectors (i.e. public and private sectors) respectively.

Table 2. Experts' profile (Osei-Kyei, Chan 2017)

\begin{tabular}{lll}
\hline Demographic variables & $\begin{array}{l}\text { No. of } \\
\text { respondents }\end{array}$ & $\begin{array}{l}\text { Percentage } \\
(\%)\end{array}$ \\
\hline Type of sector & 18 & 43 \\
Academia & 57 \\
$\begin{array}{l}\text { Industrial sector (public } \\
\text { and private) }\end{array}$ & 24 & 100 \\
Total 42 & \\
Number of PPP projects involved & 59 \\
Less than 3 projects & 25 & 10 \\
3 & 4 & 31 \\
More than 3 projects & 13 & \\
Total 42 100 & & \\
Years of industrial and/or research experience in \\
PPPs & & 14 \\
5 years and below & 6 & 26 \\
$6-10$ years & 11 & 31 \\
11-15 years & 13 & 29 \\
16 years and above & 12 & 100 \\
Total & 42 & \\
\hline
\end{tabular}

Table 3. Countries of experts (Osei-Kyei, Chan 2017)

\begin{tabular}{lll}
\hline Region & Countries & No. of experts \\
\hline Africa & South Africa & 1 \\
& Kenya & 1 \\
Asia & Nigeria & 2 \\
& Bangladesh & 1 \\
& China & 1 \\
& Australia & 13 \\
Europe & Indonesia & 1 \\
& Hong Kong & 1 \\
& Portugal & 2 \\
& UK & 5 \\
& Switzerland & 1 \\
& Netherlands & 1 \\
& France & 3 \\
& Spain & 2 \\
North America & Greece & 1 \\
& USA & 2 \\
& Canada & 3 \\
& Brazil & 1 \\
& Total & 42 \\
\hline \multirow{5}{*}{ America } & & \\
& & \\
& & \\
& & \\
& &
\end{tabular}


Moreover, experts from 18 different countries representing five regions globally (Africa, Asia, South America, North America and Europe) participated in this study. However, more of the responses came from Australia and the U.K. This is not surprising considering that these countries have witnessed a large number of successful PPP projects; therefore more experts from these countries satisfied the selection criteria. This further reaffirms the rich information and reliability of results from this research.

\subsection{Analytical techniques}

The Statistical Package for Social Sciences 21.0 was used to perform statistical tests including reliability analysis using the Cronbach's alpha, Kendall's coefficient of concordance $(W)$ and mean significance analysis.

\subsubsection{Reliability analysis (Cronbach's alpha)}

The validity and reliability of the survey data was statistically determined using the Cronbach's alpha. The values for Cronbach's alpha model ranges between 0 to 1 , where an alpha value greater that 0.70 is considered acceptable, signifying good internal consistency and reliability of the data set (George, Mallery 2003; Nunnally 1978).

\subsubsection{Kendall's concordance analysis}

The Kendall's concordance analysis was conducted to measure the degree of consensus among experts on the rankings of the success criteria for PPP projects (Cheung, Chan 2011). The Kendall's coefficient of concordance $(W)$ value ranges between 0 and +1 , where a value close to 1 implies a strong agreement among respondents and vice versa (Sheskin 2011). Additionally a predefined significance level of 0.05 was set for $(W)$ with a null hypothesis that "there is no significant agreement among experts on the rankings". In this regard, Kendall's coefficient of concordance $(W)$ value with a significance test below 0.05 renders the null hypothesis to be rejected. However as suggested by Siegel and Castellan (1988), Kendall's $W$ test is only appropriate when the number of attributes $(N)$ is less than 7 . If $N$ is greater than 7 then chi-square $\left(x^{2}\right)$ test value is used as near approximation. This suggests that if the chisquare $\left(x^{2}\right)$ calculated value is greater than the tabulated value (critical value of $x^{2}$ ), the null hypothesis should be rejected.

\subsubsection{Mean significance analysis}

The mean significance analysis was performed to ascertain the relative importance/criticality of each criterion for determining the success of PPP projects (Zhang 2006b). It is assumed that the responses follow a normal distribution pattern which requires $95 \%$ of the data set to lie within two standard deviations $(2 \sigma)$ of the mean $(\mu)$, that is within $(\mu-2 \sigma, \mu+2 \sigma)$ (Zhang 2006b). In this regard, responses that lie outside $(\mu-2 \sigma, \mu+2 \sigma)$ are considered outliers and are removed. After the removal of outliers, the mean significance index $\left(\mu_{1}\right)$ for each criterion is recalculated and forms the basis for the ranking of factors.

\section{RESULTS AND DISCUSSIONS}

\subsection{Reliability and validity of survey results}

The Cronbach's alpha value for the set of 15 success criteria for PPP projects is 0.781 , which is within the acceptable range (George, Mallery 2003). This indicates the excellent uniformity of responses and reliability of the research instrument (Norusis 2008).

\subsection{Agreement and consistency of responses}

The Kendall's coefficient of concordance $(W)$ value was computed at a significance level of 0.05 with a null hypothesis that "there is no agreement or consensus among experts on the rankings of the success criteria for PPP projects". The computed $W$ is 0.258 with a significance test value of 0.00 .

As previously indicated the chi-square $\left(x^{2}\right)$ value is used as a near approximation when the number of elements $(N)$ are more than 7 (Siegel, Castellan 1988). Given the degree of freedom for the computed chi-square $\left(x^{2}\right)$ value to be 14 , the tabulated critical value of chi-square is 23.685 , (95\% confidence interval) which is lower than the computed chi-square value of 151.520 . This required the null hypothesis to be rejected suggesting that there is significant agreement among experts on the rankings of the 15 success criteria for PPP projects. This also signifies the validity of the survey data for further analysis (Chan et al. 2010).

\subsection{Ranking of PPP projects success criteria by experts}

The mean index for each criterion is presented in Tables 4 and 5 . Table 4 shows the mean index $\left(\mu_{1}\right)$ and standard deviation $(\sigma)$ of each criterion prior 
Table 4. Mean indices of PPP projects success criteria prior to removal of outliers

\begin{tabular}{|c|c|c|c|c|c|c|c|c|c|}
\hline \multirow[t]{2}{*}{ PPP projects success criteria } & \multicolumn{7}{|c|}{ Number of responses } & \multirow{2}{*}{$\begin{array}{l}\text { Mean significance } \\
\text { index }\left(\mu_{1}\right)\end{array}$} & \multirow{2}{*}{$\begin{array}{l}\text { Standard } \\
\text { deviation }(\sigma)\end{array}$} \\
\hline & 1 & 2 & 3 & 4 & 5 & 6 & 7 & & \\
\hline Effective risk management & 0 & 0 & 0 & 0 & 7 & 17 & 18 & 6.26 & 0.73 \\
\hline Meeting output specifications & 0 & 0 & 0 & 2 & 10 & 20 & 10 & 5.90 & 0.82 \\
\hline Reliable and quality service operations & 0 & 0 & 0 & 1 & 11 & 26 & 4 & 5.79 & 0.65 \\
\hline Adherence to time & 0 & 0 & 0 & 3 & 15 & 17 & 7 & 5.67 & 0.85 \\
\hline Satisfying the need for public facility/service & 0 & 0 & 0 & 5 & 12 & 19 & 6 & 5.62 & 0.88 \\
\hline Profitability & 0 & 0 & 0 & 6 & 10 & 22 & 4 & 5.57 & 0.86 \\
\hline Long-term relationship and partnership & 0 & 0 & 0 & 1 & 20 & 18 & 3 & 5.55 & 0.67 \\
\hline Adherence to budget & 0 & 0 & 0 & 5 & 19 & 15 & 3 & 5.38 & 0.79 \\
\hline Reduced litigations and disputes & 0 & 0 & 0 & 6 & 20 & 15 & 1 & 5.26 & 0.73 \\
\hline Reduced public administrative cost & 0 & 0 & 0 & 6 & 24 & 10 & 2 & 5.19 & 0.74 \\
\hline Environmental performance & 0 & 0 & 1 & 9 & 19 & 12 & 1 & 5.07 & 0.84 \\
\hline Effective technology transfer and innovation & 0 & 0 & 3 & 10 & 14 & 14 & 1 & 5.00 & 0.99 \\
\hline Local economic development & 0 & 0 & 3 & 8 & 21 & 7 & 3 & 4.98 & 0.98 \\
\hline Reduced project life cycle cost & 0 & 1 & 3 & 9 & 16 & 13 & 0 & 4.88 & 1.02 \\
\hline Reduced public and political protests & 0 & 0 & 1 & 17 & 20 & 2 & 2 & 4.69 & 0.81 \\
\hline
\end{tabular}

to the removal of outliers. Table 5 presents the mean index $\left(\mu_{2}\right)$ after the removal of outliers and forms the basis for the rankings.

However, in labelling the importance of each criterion, an interval scale description is adopted, where a criterion with mean index $\left(\mu_{2}\right) \leq 1.4,1.5$ $\leq \mu_{2} \leq 2.4,2.5 \leq \mu_{2} \leq 3.4,3.5 \leq \mu_{2} \leq 4.4,4.5 \leq \mu_{2} \leq$ $5.4,5.5 \leq \mu_{2} \leq 6.4$ and $\mu_{2} \geq 6.5$ is considered as "extremely low critical", "very low critical", "low critical", "moderate", "critical", "very critical", and "extremely critical" respectively. As shown in Table 5, all the 15 success criteria for PPP projects are critical with indices ranging between 4.73 and 6.26. Nonetheless, seven success criteria emerge as very critical in determining PPP project success; these include: effective risk management, meeting output specifications, reliable and quality service operations, adherence to time, satisfying the need for public facility/service, long-term relationship and partnership, and profitability.

Effective risk management ranks first among the very critical PPP projects success criteria. It has an index of 6.26 prior to the removal of outliers, however because all responses for this criterion are within the two standard deviations (4.79 and 7.73), outliers are not identified. Interestingly, majority of past studies on success criteria did not identify effective risk management as an essential projects success criterion (Lim, Mohamed 1999; Bryde, Brown 2005; Ahadzie et al. 2008; AlTmeemy et al. 2011). This is quite understandable considering the fact that previous studies focused more on the traditionally procured projects, where risk sharing and allocation is not important as ap- plied in PPP projects. Essentially, risk management is a key component of PPP project management (Ke et al. 2010). It encompasses the identification, assessment, allocation and treatments of risks (Chan et al. 2011). For effective risk management to be realised, risks (i.e. both country and project risk factors) have to be properly identified using different identification mechanisms including brainstorming, cause and effect diagram and project analogy (Ozdoganm, Birnogul 2000; Medda 2007). Moreover, the risk sharing and transfer mechanism have to be agreed among parties and effectively implemented. Unlike, the objective success measures of time, cost and quality (Chan, A. P. C., Chan, A. P. 2004); effective risk management is rather subjective and may not be easily measured. As pointed out by Cox et al. (2003); the subjective measures of success should not be undermined by project managers when evaluating projects success. Therefore, effective risk management could be assessed using a Likert scale, where each project participant evaluates the effectiveness level of risk management of the given PPP project.

The second ranked PPP project success criterion is 'meeting output specifications'. This criterion has a mean index of 5.9 prior to the removal of outliers. Two responses (see Table 4) are considered as outliers because they fall outside the range of 4.26 and 7.55. The recalculated mean index is 6.00, which is labelled as very critical in determining PPP projects success. Previous studies including Dixon et al. (2005) also identified meeting specifications as a key success criterion for PFI/PPP projects. In addition, past studies that focused on 
Table 5. Mean indices and rankings of success criteria for PPP projects

\begin{tabular}{|c|c|c|c|c|c|c|}
\hline PPP projects success criteria & $\begin{array}{l}\text { Standard } \\
\text { deviation } \\
(\sigma)\end{array}$ & $\mu_{1}-2 \sigma$ & $\mu_{1}+2 \sigma$ & $\begin{array}{l}\text { Sig. Index } \\
\left(\mu_{2}\right)\end{array}$ & Rank & Criticality \\
\hline Effective risk management & 0.73 & 4.79 & 7.73 & 6.26 & 1 & Very Critical \\
\hline Meeting output specifications & 0.82 & 4.26 & 7.55 & 6.00 & 2 & Very Critical \\
\hline Reliable and quality service operations & 0.65 & 4.50 & 7.08 & 5.83 & 3 & Very Critical \\
\hline Adherence to time & 0.85 & 3.97 & 7.36 & 5.67 & 4 & Very Critical \\
\hline Satisfying the need for public facility/service & 0.88 & 3.85 & 7.38 & 5.62 & 5 & Very Critical \\
\hline Long-term relationship and partnership & 0.67 & 4.21 & 6.89 & 5.57 & 6 & Very Critical \\
\hline Profitability & 0.86 & 3.85 & 7.29 & 5.57 & 7 & Very Critical \\
\hline Adherence to budget & 0.79 & 3.79 & 6.97 & 5.38 & 8 & Critical \\
\hline Reduced litigations and disputes & 0.73 & 3.79 & 6.73 & 5.26 & 9 & Critical \\
\hline Reduced public administrative cost & 0.74 & 3.71 & 6.67 & 5.19 & 10 & Critical \\
\hline Effective technology transfer and innovation & 0.99 & 3.02 & 6.98 & 5.15 & 11 & Critical \\
\hline Local economic development & 0.98 & 3.03 & 6.93 & 5.13 & 12 & Critical \\
\hline Environmental performance & 0.84 & 3.40 & 6.75 & 5.12 & 13 & Critical \\
\hline Reduced project life cycle cost & 1.02 & 2.85 & 6.91 & 4.95 & 14 & Critical \\
\hline Reduced public and political protests & 0.81 & 3.07 & 6.31 & 4.73 & 15 & Critical \\
\hline
\end{tabular}

the traditionally procured projects also mentioned adherence to specifications as a success measure (Al-Tmeemy et al. 2011; Chan et al. 2002). Actually, meeting specifications/technical requirements is mostly grouped under the category of "quality" (Chan, A. P. C., Chan, A. P. 2004) and some studies have even used quality and meeting technical specifications interchangeably (Baccarini 1999; Lai, Lam 2010). In measuring PPP projects success, meeting output specifications denotes compliance with the expected output standards/requirements of the facility/service. Basically, output specifications are preferred compared to input specifications in PPP contracts (Lam, Javed 2015). This is because output specification allows the private consortium to adopt innovative and creative approaches in delivering the project (Cheung et al. 2009). In this regard, private investors are expected to construct and operate PPP projects according to the output requirements provided by the procuring authority. A clear and concise output requirement is a key critical factor, which contributes in achieving this success criterion (Lam, Javed 2015). It is therefore essential that procuring authorities would provide very clear and sufficient information to the private partner on the output requirements of PPP projects.

Reliable and quality service operations ranks third among the very critical success criteria for PPP projects. It scores a mean index of 5.79 before the removal of outliers. One response falls outside the two standard deviations; 4.50 and
7.08 and is removed. The recalculated mean index is 5.83. Importantly, the normative literature groups this success criterion under the category of user/customer satisfaction (Chan, A. P. C., Chan, A. P. 2004; Al-Tmeemy et al. 2011). This is because providing reliable and quality service delivery for public facilities is mostly aimed towards the satisfaction of users/customers. The general public and users are the ones who are commonly affected when services of public facilities are poorly delivered and unreliable (Meng et al. 2011). Therefore, it is very important that private investors would employ proper measures including planned maintenance to enable a reliable and quality service delivery at the operational phase of PPP projects (Ng et al. 2012). Similarly, procuring authorities should consistently monitor the service delivery offered by the private sector. Obviously, this success measure is very subjective compared to the traditional success measures, hence a Likert scale point could be used by stakeholders for evaluation (Chan, A. P. C., Chan, A. P. 2004).

The fourth ranked success criterion is 'adherence to time'. It has a mean index of 5.67, which is considered very critical in determining PPP projects success. Generally, time is among the three elements of the iron triangle, which is conventionally used to assess the success of construction projects (Atkinson 1999; Lim, Mohammed 1999; Chan et al. 2002). It refers to the duration for completing a project (Chan, A. P. C., Chan, A. P. 2004). Adherence to time is essential 
in measuring the success of PPP projects because it has a direct repercussion on investments returns. This is because projects completed on or before time offer investors the opportunity to recoup their investments costs earlier. This is one of the possible reasons why many PPP projects globally including the Cross Harbour Tunnel (Hong Kong) and N4 Toll Road (South Africa) (Kumaraswamy, Zhang 2001; Osei-Kyei, Chan 2015) were completed before their anticipated time schedule. In essence, several critical factors contribute in meeting time schedule in PPP projects. These include: detailed project planning, streamline of approval process, good feasibility studies, political support, public/community support, and clear project brief and design development (Cheung et al. 2012; Babatunde et al. 2012). Time performance is objective and can be measured using different approaches. Chan, A. P. C. and Chan, A. P. (2004) pointed out three ways of measuring time; these include: time variation, construction time and speed of construction.

Satisfying the need for public facility/service ranks fifth with a mean index of 5.62 and it is very critical in measuring PPP projects success. Outliers are not identified for this criterion, which suggests that all responses were within the range of 3.85 and 7.38. This criterion is one of the success measures peculiar to PPP projects (Yuan et al. 2009). Previous studies did not consider this criterion as a success measure primarily because they focused on the traditionally procured construction projects. Before PPP projects are implemented, procuring authorities outline the reasons why a public facility/service is required through feasibility studies ( $\mathrm{Ng}$ et al. 2012). It is therefore expected that the PPP project would fully satisfy the need for the public facility/service. Critical factors including good feasibility studies, competitive procurement process, transparent PPP process, strong private consortium, open and constant communication among stakeholders, selecting the right project and technology innovations are some of the ways of meeting this success criterion (Jamali 2004; Cheung et al. 2012; Li et al. 2005a). This success measure is also very subjective and it could be measured using a Likert scale point. The criterion could be evaluated by both internal and external stakeholders.

The sixth ranked criterion among the seven very critical success criteria is "long-term relationship and partnership". It has a mean index of 5.55 before the removal of outliers. One response (see Table 4) is outside the two standard devia- tions (4.21 and 6.89) and is removed. The recalculated mean index is 5.57. Interestingly, Yeung et al. (2007) also identified long-term relationship and partnership as a key success measure. This is unsurprising considering the fact that their study focused on partnering construction projects, which is closely related to PPP projects. However, most of previous studies on projects success criteria particularly those that focused on the traditionally procured projects failed to stress the criticality of this success criterion (Lim, Mohamed 1999; Westerveld 2003; Chan, A. P. C., Chan, A. P. 2004; Bryde, Robinson 2005). PPP arrangement is a relationship between the public and private sectors which can span over 25 years (Yuan et al. 2015). Hence, the cordiality of relationship and partnership among the key project parties and stakeholders cannot be undermined when evaluating success. Long-term relationship and partnership denotes a cordial and well established coordination among project participants including external stakeholders. Apparently, for a long-term relationship and partnership to be achieved, there should be transparency, competition, openness and constant communication, public/community support and political support (Abdul-Aziz, Kassim 2011; Cheung et al. 2012). This success measure is subjective; similarly to other subjective measures it could be measured on a Likert scale point (Chan, A. P. C., Chan, A. P. 2004).

The last ranked criterion among the very critical success criteria is "profitability". This criterion did not record any outlier because all responses are within 3.85 and 7.29. Previous studies including Chan, A. P. C. and Chan, A. P. (2004), Lai and Lam (2010) and Al-Tmeemy et al. (2011) pointed out the importance of this success measure although their studies did not focus on PPP projects. Profitability connotes a continuous income stream received by project parties during the operation of PPP projects. Depending on the PPP modality adopted, the returns on investments may be received by both the public and private sectors or only the private sector. Profitability could be realised, when there is a long-term demand for the project (Ozdoganm, Birgonul 2000). In addition proper feasibility studies, stable macroeconomic conditions and reasonable user fees are also essential in achieving this success criterion (Li et al. 2005a; Babatunde et al. 2012). Profitability is measurable and as suggested by Chan, A. P. C. and Chan, A. P. (2004), a net present value (NPV) could be used for evaluation.

Among the 15 PPP projects success criteria, eight emerge as critical because their mean values 
are below 5.50 and above 4.50. These include: adherence to budget (5.38), reduced litigations and disputes (5.26), reduced public administrative cost (5.19), effective technology transfer and innovation (5.15), local economic development (5.13), environmental performance (5.12), reduced project life cycle cost (4.95) and reduced public and political protests (4.73). Adherence to budget is an element of the traditional success measure (Al-Tmeemy et al. 2011). Essentially, critical factors including good feasibility studies, technical innovation and strong private consortium are vital in realising this criterion.

Previous studies including Chan et al. (2002) and Yeung et al. (2007) also identified reduced litigations and disputes as essential success measure, though they focused on different procurement methods. Litigations and disputes may not be completely avoided in PPP projects but their occurrences and magnitudes should be minimised. Openness and constant communication, transparent PPP process, competition, public/community support and political support are critical factors that contribute in achieving this criterion.

Reduced public administrative cost is one of the success criteria specific to PPP projects. It implies a reduction in the public sector's administrative cost considering the fact that more of project risks are transferred to the private partner. Critical factors including selecting the right private partner, appropriate risk allocation and sharing, and detailed project planning contribute in achieving this success criterion.

Effective technology transfer and innovation refers to the appropriate transfer of technical knowledge and initiatives among project participants particularly local practitioners. Ahadzie et al. (2008) also identified this success criterion in mass housing building projects in developing countries. Effective technology transfer and innovation would be of great interest to countries in the developing regions because most of the PPP markets are dominated by foreign investors (Dulaimi et al. 2010). Several critical factors including innovation and creativity, and open and frequent communication among stakeholders contribute in achieving this criterion.

Another success measure peculiar to PPP projects is local economic development. Generally, PPP projects are expected to contribute significantly to the economic development and livelihood of the community within which the project is implemented. Obviously this criterion is very subjective; hence it could be measured using a Likert scale point. Both external and internal stakeholders should be involved in its evaluation.

Environmental performance is one of the subjective measures of success, which has been identified by most previous studies (Ahadzie et al. 2008; Chan, A. P. C., Chan, A. P. 2004; Lai, Lam 2010). It implies that the health and safety of occupants or environment are not negatively affected during the construction and operation of PPP projects. This criterion could be evaluated by counting the number of complaints and accidents associated with the construction and operation of a given project (Chan, A. P. C., Chan, A. P. 2004). Critical factors including thorough and in-depth environmental impact assessments contribute in realising this criterion.

Fundamentally, reduced project lifecycle cost has a tight relationship with projects' value for money. It is also one of the success measures specific to PPP projects. Reduced project lifecycle cost denotes a lower lifecycle cost of PPP projects. This criterion could be achieved through proper feasibility studies and employment of competent transaction advisors. Ideally, value for money assessments methods could be used in evaluating this criterion.

Reduced public and political protest is the last ranked criterion; however its mean value exceeds 4.50 and is therefore considered as critical. This criterion implies that public agitation and political protest are minimized in PPPs. The number of public agitation and political protest may be used to evaluate this criterion. Reduction in public agitation and political protests could be achieved through proper stakeholder consultations on toll adjustments, ensuring transparency and competition throughout the PPP process.

\section{RESEARCH LIMITATIONS AND FUTURE WORK}

The generalizability of the findings of the study is limited considering certain factors. First, the sample size is relatively low despite all efforts to maximize it. Also majority of the respondents came from the developed countries which would not accurately represent the perception of PPP experts globally (Osei-Kyei, Chan 2017). Generally, a larger sample size and more balanced cultural backgrounds (i.e. developing and developed countries) would have enhanced the representation of global experience and practice. Nonetheless, the writers take consolation from the fact that experts from 18 countries with adequate research and/or industrial experience participated in the study, 
which is bigger compared to previous related studies. Hence the results are still relevant for future reference and further investigations. Second, the 15 success criteria considered is basic and generic. They do not focus on a particular sector of PPP projects. This is because this study only sought to highlight the critical criteria for PPP projects success in general.

Future research should be conducted in a specific country/region using both face-to-face and email surveys. This will increase the response rate and provide a much better understanding of PPP projects success criteria from a specific country/ region's perspective, given that $\mathrm{PPP}$ practice and experience vary among countries. Additionally, it would facilitate a cross-country comparison of the success criteria for PPP projects. Further, future research should focus on developing a composite success index for PPP projects, examine stakeholders' perceptions on PPP projects success criteria and examine the causal relationship between CSFs and success criteria for PPP projects using advanced techniques including Structural Equation Modelling (SEM), Multiple Regression Analysis (MRA) and Fuzzy Synthetic Evaluation (FSE).

\section{CONCLUSIONS}

This paper has evaluated a set of 15 success criteria for PPP projects by means of questionnaire survey on targeted international PPP experts. Preliminary tests conducted using the Cronbach's alpha model demonstrated a good uniformity of responses and reliability of the research instrument. Additionally Kendall's concordance analysis indicated a significant agreement and consensus among experts on the rankings of the 15 success criteria for PPP projects. The mean index analysis indicated that all the 15 success criteria are critical, with indices ranging between 6.26 and 4.73. However, seven success criteria emerged as very critical; these are (in descending order): effective risk management, meeting output specifications, reliable and quality service operations, adherence to time, satisfying the need for public facility/service, profitability and long-term relationship and partnership. The other eight critical success criteria include (in descending order): adherence to budget, reduced litigations and disputes, reduced public administrative cost, effective technology transfer and innovation, local economic development, environmental performance, reduced project life cycle cost and reduced public and political protests. The findings revealed in this study are very impactful with implications for both practice and academia. First, it provides significant insights into the critical criteria for assessing PPP projects success. Second, it facilitates the formulation of relevant hypothesis for a much deeper investigation in the future.

\section{ACKNOWLEDGEMENT}

This paper forms part of a $\mathrm{PhD}$ research project entitled "A best practice framework for PPP implementation for infrastructure development in Ghana" from which other papers have been produced with different objective/scope but sharing the same background and methodology. The research project described is fully supported by the Hong Kong PhD Fellowship Scheme from the Research Grants Council (RGC) of the Hong Kong Special Administrative Region and The Hong Kong Polytechnic University, Hong Kong. Authors wish to express their sincere gratitude to all industry practitioners and researchers who participated in this research study.

\section{REFERENCES}

Abdul-Aziz, A. R.; Kassim, J. P. S. 2011. Objectives, success and failure factors of housing public-private partnerships in Malaysia, Habitat International 35(1): 150-157. https://doi.org/10.1016/j.habitatint.2010.06.005

Ahadzie, D. K.; Proverbs, D. G.; Olomolaiye, P. O. 2008. Critical success criteria for mass house building projects in developing countries, International Journal of Project Management 26: 675-687.

https://doi.org/10.1016/j.ijproman.2007.09.006

Akintoye, A.; Hardcastle, C.; Beck, M.; Chinyio, E.; Asenova, D. 2003. Achieving best value in private finance initiative project procurement, Construction Management and Economics 21(5): 461-470. https://doi.org/10.1080/0144619032000087285

Al-Tmeemy, S. M. H. M.; Abdul-Rahman, H.; Harun, Z. 2011. Future criteria for success of building projects in Malaysia, International Journal of Project Management 29(3): 337-348. https://doi.org/10.1016/j. ijproman.2010.03.003

Ameyaw, E. E.; Chan, A. P. C. 2015. Risk ranking and analysis in PPP water supply infrastructure projects: an international survey of industry experts, Facilities 33(7/8): 428-453.

https://doi.org/10.1108/F-12-2013-0091

Ashley, D. B.; Lurie, C. S.; Jaselskis, E. J. 1987. Determinants of construction project success, Project Management Journal 18(2): 69-79.

Atkinson, R. 1999. Project management: cost, time and quality, two best guesses and a phenomenon, it's time to accept other success criteria, International 
Journal of Project Management 17(6): 337-342. https://doi.org/10.1016/S0263-7863(98)00069-6

Babatunde, S. O.; Opawole, A.; Akinsiku, O. E. 2012. Critical success factors in public-private partnership (PPP) on infrastructure delivery in Nigeria, Journal of Facilities Management 10(3): 212-225. https://doi.org/10.1108/14725961211246018

Baccarini, D. 1999. The logical framework method for defining project success, Project Management Journal 30: 25-32.

Brown, A.; Adams, J. 2000. Measuring the effect of project management on construction outputs: a new approach, International Journal of Project Management 18: 327-335. https://doi.org/10.1016/S02637863(99)00026-5

Bryde, D. J.; Brown, D. 2005. The influence of project performance measurement system on the success of a contract for maintaining motorways and trunk roads, Project Management Journal 35(4): 57-65.

Bryde, D. J.; Robinson, L. 2005. Client versus contractor perspectives on project success criteria, International Journal of Project Management 23: 622-629. https://doi.org/10.1016/j.ijproman.2005.05.003

Chan, A. P. C.; Chan, A. P. 2004. Key performance indicators for measuring construction success, Benchmarking: an International Journal 11(2): 203-221.

Chan, A. P. C.; Lam, P. T.; Chan, D. W.; Cheung, E.; Ke, Y. 2009. Drivers for adopting public private partnerships-empirical comparison between China and Hong Kong special administrative region, Journal of Construction Engineering and Management 135(11): 1115-1124. https://doi.org/10.1061/(ASCE)CO.19437862.0000088

Chan, A. P. C.; Lam, P. T.; Chan, D. W.; Cheung, E.; Ke, Y. 2010. Potential obstacles to successful implementation of public-private partnerships in Beijing and the Hong Kong special administrative region, Journal of Management in Engineering 26(1): 30-40. https://doi.org/10.1061/(ASCE)0742-597X(2010)26:1(30)

Chan, A. P. C.; Scott, D.; Lam, E. W. 2002. Framework of success criteria for design/build projects, Journal of Management in Engineering 18(3): 120-128. https://doi.org/10.1061/(ASCE)0742-597X(2002) 18:3(120)

Chan, A. P. C.; Yeung, J. F.; Calvin, C. P.; Wang, S. Q.; Ke, Y. 2011. Empirical study of risk assessment and allocation of public-private partnership projects in China, Journal of Management in Engineering 27(3): 136-148. https://doi.org/10.1061/(ASCE)ME.19435479.0000049

Cheung, E.; Chan, A. 2011. Risk factors of public-private partnership projects in China: comparison between the water, power, and transportation sectors, Journal of Urban Planning Development 137(4): 409-415. https://doi.org/10.1061/(ASCE)UP.19435444.0000086

Cheung, E.; Chan, A. P. C.; Kajewski, S. 2009. Reasons for implementing public private partnership projects: perspectives from Hong Kong, Australian and British practitioners, Journal of Property Investment \& Finance 27(1): 81-95. https://doi.org/10.1108/14635780910926685
Cheung, E.; Chan, A. P. C.; Kajewski, S. 2012. Factors contributing to successful public private partnership projects, comparing Hong Kong with Australia and the United Kingdom, Journal of Facilities Management 10(1): 45-58.

https://doi.org/10.1108/14725961211200397

Cheung, S. O.; Tam, C. M.; Ndekugri, I.; Harris, F. C. 2000. Factors affecting client's project dispute resolution satisfaction in Hong Kong, Construction Management and Economic 18(3): 281-294. https://doi.org/10.1080/014461900370654

Cox, R. F.; Issa, R. R. A.; Ahrens, D. 2003. Management's perception of key performance indicators for construction, Journal of Construction Engineering and Management 129(2): 142-151. https://doi. org/10.1061/(ASCE)0733-9364(2003)129:2(142)

Cserháti, G.; Szabó, L. 2014. The relationship between success criteria and success factors in organisational event projects, International Journal of Project Management 32(4): 613-624. https://doi.org/10.1016/j. ijproman.2013.08.008

Dixon, T.; Pottinger, G.; Jordan, A. 2005. Lessons from the private finance initiative in the UK: benefits, problems and critical success factors, Journal of Property Investment \& Finance 23(5): 412-423. https://doi.org/10.1108/14635780510616016

Dulaimi, M. F.; Alhashemi, M.; Ling, F. Y. Y.; Kumaraswamy, M. 2010. The execution of public-private partnership projects in the UAE, Construction Management and Economics 28(4): 393-402. https://doi.org/10.1080/01446191003702492

Elattar, S. M. S. 2009. Towards developing an improved methodology for evaluating performance and achieving success in construction projects, Scientific Research and Essay 4: 549-554.

Frodell, M.; Josephson, P. E.; Lindahl, G. 2008. Swedish construction clients' views on project success and measuring performance, Journal of Engineering, Design and Technology 6(1): 21-32. https://doi.org/10.1108/17260530810863316

Gannon, M. J.; Smith, N. J. 2011. An effective outline business case to facilitate successful decision-making, Construction Management and Economics 29(2): 185-197. https://doi.org/10.1080/01446193.2010.538707

George, D.; Mallery, P. 2003. SPSS for windows step by step: A simple guide and reference. 11.0 update, $4^{\text {th }}$ ed. Allyn \& Bacon, Boston, MA.

Hatush, Z.; Skitmore, M. 1997. Evaluating contractor prequalification data: selection criteria and project success factors, Construction Management and Economics 15(2): 129-147. https://doi.org/10.1080/01446199700000002

Jacobson, C.; Choi, S. O. 2008. Success factors: public works and public-private partnerships, International Journal of Public Sector Management 21(6): 637-657. https://doi.org/10.1108/09513550810896514

Jamali, D. 2004. Success and failure mechanisms of public private partnerships (PPPs) in developing countries, insights from the Lebanese context, International Journal of Public Sector Management 17(5): 414-430. https://doi.org/10.1108/09513550410546598 
Jefferies, M.; Gameson, R.; Rowlinson, S. 2002. Critical success factors of the BOOT procurement system: reflections from the Stadium Australia case study, Engineering, Construction and Architectural Management 9(4): 352-361. https://doi.org/10.1108/eb021230

Ke, Y.; Wang, S.; Chan, A. P. C. 2010. Risk allocation in public-private partnership infrastructure projects: comparative study, Journal of Infrastructure Systems 16(4): 343-351. https://doi.org/10.1061/(ASCE) IS.1943-555X.0000030

Ke, Y.; Wang, S.; Chan, A. P. C.; Cheung, E. 2009. Research trend of public-private partnership in construction journals, Journal of Construction Engineering and Management 135(10): 1076-1086. https://doi. org/10.1061/(ASCE)0733-9364(2009)135:10(1076)

Khosravi, S.; Afshari, H. 2011. A success measurement model for construction projects, in Proceedings of the International Conference on Financial Management and Economics, 2-3 July 2011, Hong Kong, China, IPEDR, Vol. 11. Singapore: IACSIT Press, 186-190.

Kumaraswamy, M. M.; Morris, D. A. 2002. Build-operate-transfer-type procurement in Asian megaprojects, Journal of Construction Engineering and Management 128(2): 93-102. https://doi.org/10.1061/ (ASCE)0733-9364(2002)128:2(93)

Kumaraswamy, M. M.; Zhang, X. Q. 2001. Governmental role in BOT-led infrastructure development, International Journal of Project Management 19(4): 195205. https://doi.org/10.1016/S0263-7863(99)00069-1

Lai, I. K. W.; Lam, F. K. S. 2010. Perception of various performance criteria by stakeholders in the construction sector in Hong Kong, Construction Management and Economics 28(4): 377-391.

https://doi.org/10.1080/01446190903521515

Lam, P.; Javed, A. 2015. Comparative study on the use of output specifications for Australian and U.K. PPP/ PFI projects, Journal Performance Constructed Facilities 29(2). https://doi.org/10.1061/(ASCE)CF.19435509.0000554

Li, B.; Akintoye, A.; Edwards, P. J.; Hardcastle, C. 2005a. Critical success factors for PPP/PFI projects in the UK construction industry, Construction Management and Economics 23(5): 459-471. https://doi.org/10.1080/01446190500041537

Li, B.; Akintoye, A.; Edwards, P.; Hardcastle, C. 2005b. Perceptions of positive and negative factors influencing the attractiveness of PPP/PFI procurement for construction projects in the UK, Engineering Construction and Architectural Management 12(2): 125-148. https://doi.org/10.1108/09699980510584485

Lim, C. S.; Mohamed, M. Z. 1999. Criteria of project success: an exploratory re-examination, International Journal of Project Management 17: 243-248. https://doi.org/10.1016/S0263-7863(98)00040-4

Liu, J.; Love, P.; Davis, P.; Smith, J.; Regan, M. 2015. Conceptual framework for the performance measurement of public-private partnerships, Journal of Infrastructure Systems 21(1). https://doi.org/10.1061/ (ASCE)IS.1943-555X.0000210

Liu, T.; Wilkinson, S. 2011. Adopting innovative procurement techniques: obstacles and drivers for adopting public private partnerships in New Zealand, Con- struction Innovation: Information, Process, Management 11(4): 452-469.

https://doi.org/10.1108/14714171111175918

Liyanage, C.; Villalba-Romero, F. 2015. Measuring success of PPP transport projects: a cross-case analysis of toll roads, Transport Reviews 35(2): 140-161. https://doi.org/10.1080/01441647.2014.994583

Medda, F. 2007. A game theory approach for the allocation of risks in transport public private partnerships, International Journal of Project Management 25(3): 213-218.

https://doi.org/10.1016/j.ijproman.2006.06.003

Menard, C.; Peeroo, A. 2011. Liberalization in the water sector: three leading models, in R. Kunneke; M. Finger (Eds.). International handbook of network industries: the liberalization of infrastructures. Edward Elgar, 310-327.

Meng, X.; Zhao, Q.; Shen, Q. 2011. Critical success factors for transfer-operate-transfer urban water supply projects in China, Journal of Management in Engineering 27(4): 243-251. https://doi.org/10.1061/ (ASCE)ME.1943-5479.0000058

Mladenovic, G.; Vajdic, N.; Wundsch, B.; TemeljotovSalaj, A. 2013. Use of key performance indicators for PPP transport projects to meet stakeholders' performance objectives, Built Environment Project and Asset Management 3(2): 228-249.

https://doi.org/10.1108/BEPAM-05-2012-0026

Ng, S. T.; Wong, Y. M.; Wong, J. M. 2012. Factors influencing the success of PPP at feasibility stage-a tripartite comparison study in Hong Kong, Habitat International 36(4): 423-432. https://doi.org/10.1016/j. habitatint.2012.02.002

Nisar, T. M. 2013. Implementation constraints in social enterprise and community public private partnerships, International Journal of Project Management 31(4): 638-651. https://doi.org/10.1016/j.ijproman.2012.08.004

Norusis, M. J. 2008. SPSS 16.0 advanced statistical procedures companion. Upper Saddle River, N.J.: Prentice-Hall.

Nunnally, J. C. 1978. Psychometric theory. $2^{\text {nd }}$ ed. New York: McGraw-Hill.

Osei-Kyei, R.; Chan, A. P. C. 2015. Review of studies on the critical success factors for public-private partnership (PPP) projects from 1990 to 2013, International Journal of Project Management 33(6): 1335-1346. https://doi.org/10.1016/j.ijproman.2015.02.008

Osei-Kyei, R.; Chan, A. P. C. 2016. Developing transport infrastructure in Sub-Saharan Africa through public-private partnerships: policy practice and implications, Transport Reviews 36(2): 170-186. https://doi.org/10.1080/01441647.2015.1077288

Osei-Kyei, R.; Chan, A. P. C. 2017. Perceptions of stakeholders on the critical success factors for operational management of public-private partnership projects, $F a$ cilities 35(1/2). http://dx.doi.org/10.1108/F-10-2015-0072

Osei-Kyei, R.; Dansoh, A.; Ofori-Kuragu, J. K. 2014. Reasons for adopting public-private partnership (PPP) for construction projects in Ghana, International Journal of Construction Management 14(4): 227-238. https://doi.org/10.1080/15623599.2014.967925 
Ozdoganm, I. D.; Birgonul, M. T. 2000. A decision support framework for project sponsors in the planning stage of build-operate-transfer (BOT) projects, Construction Management and Economics 18(3): 343353. https://doi.org/10.1080/014461900370708

Parfitt, M. K.; Sanvido, V. E. 1993. Checklist of critical success factors for building projects, Journal of Management Engineering 9(3): 243-249. https://doi. org/10.1061/(ASCE)9742-597X(1993)9:3(243)

Rockart, J. F. 1982. The changing role of the information systems executive: a critical success factors perspective, Sloan Management Review 24(1): 3-13.

Rosenau, M. D. 1984. Project management for engineers. Lifetime Learning Pub. University of Michigan, US.

Sachs, T.; Tiong, R. L. K.; Wang, S. Q. 2007. Analysis of political risks and opportunities in public private partnerships (PPP) in China and selected Asian countries - survey results, Chinese Management Studies 1(2): 126-148. https://doi.org/10.1108/17506140710758026

Salman, A. F.; Skibniewski, M. J.; Basha, I. 2007. BOT viability model for large-scale infrastructure projects, Journal of Construction Engineering and Management 133(1): 50-63. https://doi.org/10.1061/ (ASCE)0733-9364(2007)133:1(50)

Sheskin, D. J. 2011. Handbook of parametric and nonparametric statistical procedures. $5^{\text {th }}$ ed. FL: Chapman and Hall/CRC.

Siegel, S.; Castellan, N. J. 1988. Nonparametric statistics for the behavioral sciences. $2^{\text {nd }}$ ed. New York: McGraw-Hill.

Skietrys, E.; Raipa, A.; Bartkus, E. V. 2008. Dimensions of the efficiency of public-private partnership, Inzinerine Ekonomika-Engineering Economics 3(58): 45-50.

Toor R. S.; Ogunlana, S. O. 2010. Beyond the 'iron triangle': stakeholder perception of key performance indicators (KPIs) for large-scale public sector development projects, International Journal of Project Management 28(3): 228-236. https:doi.org/10.1016/j. ijproman.2009.05.005

Westerveld, E. 2003. The project excellence model: linking success criteria and critical success factors, International Journal of Project Management 21(6): 411-418. https://doi.org/10.1016/S0263-7863(02)00112-6
World Bank. 2015. Private participation in infrastructure (PPI), Regional Snapshots [online]. Washington, DC. Available at: http://ppi.worldbank.org/explore/ppi_exploreRegion.aspx?regionID=1 [accessed May 2015]

Yeung, J. F.; Chan, A. P. C.; Chan, D. W.; Li, L. K. 2007. Development of a partnering performance index (PPI) for construction projects in Hong Kong: a Delphi study, Construction Management and Economics 25(12): 1219-1237. https://doi.org/10.1080/01446190701598673

Yuan, J.; Chan, A. P. C.; Xiong, W.; Skibniewski, M. J.; Li, Q. 2015. Perception of residual value risk in public private partnership projects: critical review, Journal of Management in Engineering 31(3). https://doi. org/10.1061/(ASCE)ME.1943-5479.0000256

Yuan, J.; Wang, C.; Skibniewski, M.; Li, Q. 2012. Developing key performance indicators for public-private partnership projects: questionnaire survey and analysis, Journal of Management in Engineering 28(3): 252-264. https://doi.org/10.1061/(ASCE)ME.19435479.0000113

Yuan, J.; Zeng, A. Y.; Skibniewski, M. J.; Li, Q. 2009. Selection of performance objectives and key performance Indicators in public-private partnerships projects to achieve value for money, Construction Management and Economics 27(3): 253-270. https://doi.org/10.1080/01446190902748705

Zhang, X. 2006a. Factor analysis of public clients' bestvalue objective in public-privately partnered infrastructure projects, Journal of Construction Engineering and Management 132(9): 956-965. https://doi. org/10.1061/(ASCE)0733-9364(2006)132:9(956)

Zhang, X. 2006b. Public clients' best value perspectives of public private partnerships in infrastructure development, Journal of Construction Engineering and Management 132(2): 107-114. https://doi.org/10.1061/ (ASCE)0733-9364(2006)132:2(107)

Zhang, X. Q. 2005. Critical success factors for publicprivate partnerships in infrastructure development, Journal of Construction Engineering and Management 131(1): 3-14. https://doi.org/10.1061/ (ASCE)0733-9364(2005)131:1(3)

Zou, W.; Kumaraswamy, M.; Chung, J.; Wong, J. 2014. Identifying the critical success factors for relationship management in PPP projects, International Journal of Project Management 32(2): 265-274. https://doi.org/10.1016/j.ijproman.2013.05.004 